\title{
Paraspinal extraskeletal Ewing's sarcoma: a rare clinical entity
}

\author{
Chandramohan Sharma, Kunal Nath, Banshi Lal Kumawat, Mihir Acharya, \\ Dinesh Khandelwal, Deepak Jain
}

Department of Neurology, Sawai Man Singh Medical College and Hospital, Jaipur, Rajasthan, India

Correspondence to Professor Chandramohan Sharma,

cmsharma65@hotmail.com

Accepted 25 April 2014

\section{DESCRIPTION}

A 10-year-old boy presented with a 6 -month history of pain in the back (thoracic region), followed by progressive sensory and motor paraparesis with urinary incontinence.

MRI of the dorsal spine revealed a well-defined collection in the prevertebral and paravertebral regions extending from D6 vertebral body to D11-D12 intervertebral disc level (figure 1). The mass was hypointense on T1-weighted image, hyperintense on T2-weighted image and showed heterogeneous contrast enhancement. The mass also displaced the thoracic aorta laterally (figure 2). The dorsal vertebral bodies were hyperintense on T2, but there was no destruction of the vertebral bodies and the disc space was also normal, hence ruling out a primary infective process of the spine such as tuberculosis. There was possibility of metastasis and small-round-cell malignancies.

Subsequently, CT-guided fine needle aspiration cytology (FNAC) was performed and it showed clusters of small uniform round lymphocyte cells, with vacuolated scanty cytoplasm surrounding round nuclei with small nucleoli, with few scattered atypical lymphoid cells. The cells stained positive for periodic acid Schiff stain (PAS), hence suggesting high glycogen content of the cytoplasm. The peripheral blood picture was normal.

The histological findings were suggestive of small-round-cell malignancy, most probably Ewing's sarcoma.

The extraskeletal Ewing's sarcoma, being a rare entity, ${ }^{1}$ differs from the skeletal form in several

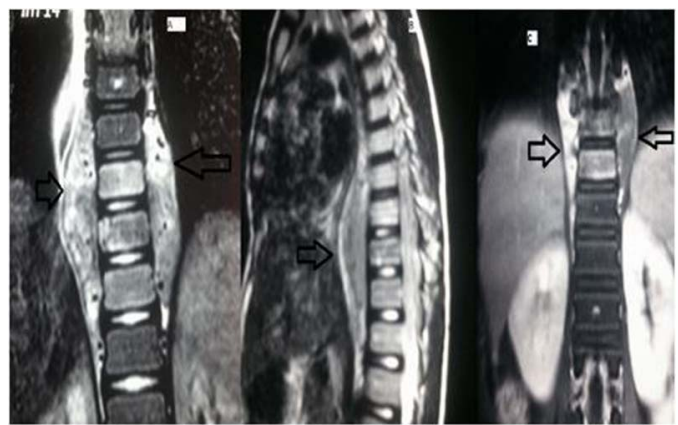

Figure 1 (A) Short tau inversion recovery (STIR) MRI coronal image (dorsal spine) showing well defined, vertically elongated hyperintense mass in bilateral paravertebral region (arrow) The vertebral bodies are hyperintense. (B) STIR MRI sagittal image (dorsal spine) showing a well defined, vertically elongated hyperintense mass in the prevertebral region (arrow) extending from D6 vertebral body to D11-D12 intervertebral level. (C) STIR MRI coronal image (dorsal spine) showing the same mass in paravertebral region.

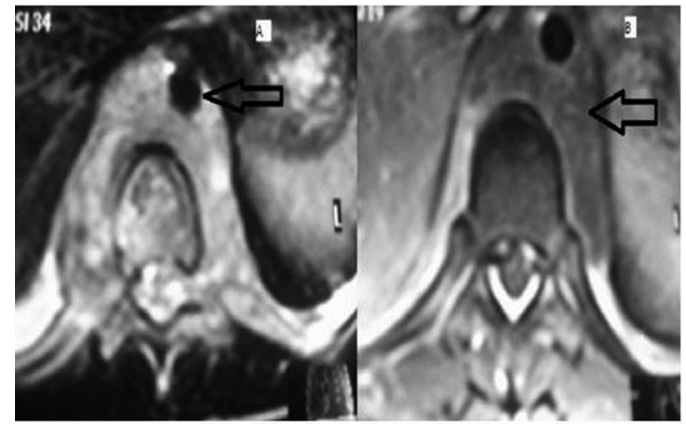

Figure 2 (A) Axial MRI (dorsal spine) postcontrast image showing a well-defined mass in the prevertebral and paravertebral regions which shows heterogeneous contrast enhancement. The mass is seen displacing thoracic aorta laterally (arrow). (B) Axial MRI STIR (dorsal spine) image which shows the mass is hyperintense and displaces aorta laterally (arrow).

respects. The average age of presentation is 20 years while that of the skeletal form is 10 years. $^{2}$ The extraskeletal Ewing's sarcoma is present equally in men and women whereas the skeletal form has a male predilection. ${ }^{2}$ Extraskeletal Ewing's sarcoma has predilection for the soft tissues of the trunk like paravertebral and intercoastal regions. $^{2}$ The paravertebral location is described in $12-31 \%$ of cases. ${ }^{2}$ In our patient the tumour was located in the prevertebral and paravertebral regions. The tumour tends to spread locally, infiltrating deep fascial spaces and invading adjacent structures. In our case it invaded the nerve foramina and displaced the thoracic aorta laterally.

\section{Learning points}

- Paraspinal extraskeletal Ewing's sarcoma though being a rare entity should be kept in the differential of prevertebral and paravertebral mass especially in children and young adults.

- With good surgical excision and chemoradiotherapy a fair prognosis can be expected.

- The preservation of the intervertebral disc architecture and lack of destruction of the vertebra are the imaging points in favour of a paraspinal Ewing's sarcoma as compared to a paraspinal tubercular abscess.

Contributors All the authors have contributed to the planning, conduct and reporting of the work described in the article and are justifiably credited with authorship, according to the authorship criteria. All the authors have read and approved the final manuscript. CMS is the guarantor for the submitted manuscript. 
Competing interests None.

Patient consent Obtained.

Provenance and peer review Not commissioned; externally peer reviewed.

\section{REFERENCES}

1 Peroulli $\mathrm{E}$, Chrysikopoulos $\mathrm{H}$, Vlachos $\mathrm{A}$, et al. Imaging findings in paraspinal extraosseus Ewing sarcoma. JBR-BTR 2006;89:310-12.

2 Shin JH, Lee HK, Rhim SC, et al. Spinal epidural extraskeletal Ewing sarcoma: MR findings in two cases. Am J Neuroradiol 2001;22:795-8.

Copyright 2014 BMJ Publishing Group. All rights reserved. For permission to reuse any of this content visit

http://group.bmj.com/group/rights-licensing/permissions.

BMJ Case Report Fellows may re-use this article for personal use and teaching without any further permission.

Become a Fellow of BMJ Case Reports today and you can:

- Submit as many cases as you like

- Enjoy fast sympathetic peer review and rapid publication of accepted articles

- Access all the published articles

- Re-use any of the published material for personal use and teaching without further permission

For information on Institutional Fellowships contact consortiasales@bmjgroup.com

Visit casereports.bmj.com for more articles like this and to become a Fellow 